\title{
Azonnali visszajelző rendszer bevezetése a kézhigiéné gyakorlatába intenzív osztályon
}

\author{
Mogyoródi Bence dr. ${ }^{1}$ - Szabó Marcell dr. ${ }^{1}$ - Dunai Erzsébet ${ }^{1}$ \\ Mester Bianka ${ }^{2}$ - Hermann Csaba dr. ${ }^{1}$ - Gál János dr. ${ }^{1}$. Iványi Zsolt dr. ${ }^{1}$ \\ ${ }^{1}$ Semmelweis Egyetem, Általános Orvostudományi Kar, Aneszteziológiai és Intenzív Terápiás Klinika, Budapest \\ ${ }^{2}$ Semmelweis Egyetem, Általános Orvostudományi Kar, Kórházhigiénés Osztály, Budapest
}

\begin{abstract}
Bevezetés: A hospitalizált, és különösen a kritikus állapotú páciensek körében 30-50\%-ot is meghaladó incidenciával fordul elő nosocomialis infekció, jelentősen rontva a morbiditási és mortalitási adatokat. A megelőzésben a multimodális prevenciós stratégiák bizonyultak hatékonynak. Ezek alappillére a megfelelő kézhigiénés gyakorlat, mely a kézfertőtlenítés helyes technikáját és indikációját is magában foglalja.

Célkitüzés: Munkánk célja az volt, hogy megvizsgáljuk intenzív osztályunk kézhigiénés gyakorlatát a kézfertőtlenítés technikájáról azonnali visszajelzést adó rendszer bevezetésével és a kézhigiénés compliance ellenőrzésével.

Módszer: A Semmelweis Egyetem Aneszteziológiai és Intenzív Terápiás Klinikájának Központi Intenzív Osztályán 2018 novemberében és decemberében háromhetes megfigyeléses vizsgálatot végeztünk. Az ellátószemélyzet kézhigiénés technikájára és compliance-ére vonatkozó adatokat Semmelweis Scannerrel és direkt obszerváció során rögzítettük. A statisztikai elemzést Kruskal-Wallis-próbával, Fisher-féle egzakt teszttel és $\chi^{2}$-teszttel végeztük.

Eredmények: Az elektronikus visszajelző rendszerrel 604 mérést rögzítettünk. A megfelelő kézfertőtlenítések aránya 86,5\%, a kézterületek lefedettségének medián értéke pedig 99,87\% volt. A kézfertőtlenítés technikájában konstansan magas trendet figyeltünk meg. A gyógytornászok csoportjára alacsonyabb hibaarány volt jellemző a többi csoporttal szemben (orvosok: $\mathrm{p}<0,01$, ápolók: $\mathrm{p}=0,03$, segédápolók: $\mathrm{p}=0,03$ ). A direkt obszerváció során 162 megfigyelést végeztünk. Az átlagos compliance $60,49 \%$ volt, a legalacsonyabbnak az orvosok csoportjában $(53,97 \%)$ adódott, mely nem különbözött szignifikánsan az ápolók compliance-étől $(62,92 \%, \mathrm{p}=0,26)$.

Következtetés: A kézfertőtlenítés technikája a vizsgálat ideje alatt végig minden csoportban kiemelkedőnek és megfelelőnek bizonyult, a kézhigiénés compliance azonban az elvártnál alacsonyabb volt. Az azonnali visszajelzésnek a kézhigiéné megfelelő minőségének elérésében és fenntartásában lehet szerepe, míg a helyes időzítés más stratégiát is szükségessé tesz.
\end{abstract}

Orv Hetil. 2019; 160(49): 1957-1962.

Kulcsszavak: közegészségügy, infekciókontroll, kézhigiéné

\section{Implementation of immediate feedback system into hand hygiene practice in the intensive care unit}

Introduction: Infections affect about $30-50 \%$ of intensive care unit patients resulting in substantial morbidity and mortality. Multimodal interventions proved to be successful in the prevention of healthcare-associated infections. Appropriate hand hygiene including correct disinfection technique and timing is essential.

Aim: The aim of our study was to investigate the hand hygiene practice among the intensive care unit healthcare workers by immediate feedback system implementation and compliance study.

Method: A 3-week-long observational study was conducted at the Department of Anaesthesiology and Intensive Therapy, Semmelweis University, during November and December, 2018. Data regarding hand hygiene technique were collected by using the Semmelweis Scanner technology, while compliance data were recorded by direct observations. Statistical analysis was performed by Kruskal-Wallis test, Fisher's exact test and $\chi^{2}$-test.

Results: 604 measurements were recorded by the electronic system. Hand disinfection was appropriate in $86.5 \%$ of cases. The median value of coverage was $99.87 \%$. The trend of these indices showed persistently high values. A lower error rate was observed in the physiotherapy group compared to others (doctors: $p<0.01$, nurses: $p=0.03$, assistant nurses: $\mathrm{p}=0.03$ ). 162 opportunities were recorded during direct observations. The mean compliance rate was 
$60.49 \%$, with the lowest among doctors $(53.97 \%)$. The difference was non-significant compared to nurses $(62.92 \%$, $\mathrm{p}=0.26)$.

Conclusions: Hand hygiene technique during the study period was found to be highly and permanently appropriate, while compliance was lower than expected. The immediate feedback system may be useful in achieving appropriate hand disinfection technique, although further interventions are needed for higher compliance rates.

Keywords: public health, infection control, hand hygiene

Mogyoródi B, Szabó M, Dunai E, Mester B, Hermann Cs, Gál J, Iványi Zs. [Implementation of immediate feedback system into hand hygiene practice in the intensive care unit]. Orv Hetil. 2019; 160(49): 1957-1962.

(Beérkezett: 2019. május 20.; elfogadva: 2019. június 23.)

\begin{abstract}
Rövidítések
ITO = (intensive care unit) intenzív terápiás osztály; WHO = (World Health Organization) Egészségügyi Világszervezet
\end{abstract}

Az egészségügyi ellátással összefüggő fertőzések prevalenciája Európában és világszerte is jelentős mértékü $[1,2]$. Az infekciók előfordulása az invazív orvosi eszközök használatával és a kritikus állapotú betegek esetében még gyakoribb, az intenzív terápiás osztályokon (ITO) megközelítőleg a páciensek 51\%-át érinti [3]. Az ITO-n szerzett nosocomialis infekciók nemcsak a mortalitást növelik, de a kezelés időtartamának és költségvonzatának tekintetében is rosszabb kimenetellel függenek össze [4-6]. Az Egészségügyi Világszervezet (World Health Organization, WHO) multimodális prevenciós intézkedéseket javasol az egészségügyi ellátással összefüggő fertőzések megelőzésére [7], mely alapelv az ITO infekciókontroll-gyakorlatában is megjelenik $[8,9]$.

A „prevenciós csomagok” kiemelt része a kézhigiéné, mely magában foglal minden olyan eljárást, mely a kezeknek a szennyeződéstől, organikus anyagtól és mikroorganizmustól való megtisztítását célozza. A megfelelő kézhigiénés gyakorlat eredményesen csökkenti az egészségügyi ellátással összefüggő fertőzéseket és az antibiotikumrezisztencia terjedését [10]. Ennek következtében az elmúlt évtizedekben a kézhigiénére irányuló kutatások világszerte nőttek [11]. Ugyanakkor a legutóbbi metaanalízisek alapján a kézhigiéné magas compliance-elérésének leghatékonyabb stratégiája bizonytalan mind az ITO, mind az egyéb kórházi és ápolási osztályok tekintetében $[12,13]$. İgy a kézhigiénés protokollok betartása nemzetközi szinten is elégtelen, auditálási metodikától függően 37-79\% között alakul [14, 15]. A Magyarországon végzett, országos szintû́ vizsgálatok szintén alacsony kézhigiénés compliance-ról (62-73\%) számolnak be $[16,17]$. Célkitüzésünk az volt, hogy felmérjük osztályunk kézhigiénés gyakorlatát a kézfertőtlenítés technikájáról azonnali, elektronikus visszajelzést adó rendszer bevezetésével és a kézhigiéné betegágy melletti compliance-ének vizsgálatával. Összehasonlítottuk továbbá a különböző szakmacsoportok közötti különbségeket a fentiek tekintetében.

\section{Módszer}

A Semmelweis Egyetem Aneszteziológiai és Intenzív Terápiás Klinikájának multidiszciplináris Központi Intenzív Osztályán végeztünk obszervációs vizsgálatot. A 2018. november 5. és 2018. november 28. közötti időszakban reggelente, múszakváltást követően kerültek rögzítésre a teljes ellátószemélyzet kézfertőtlenítési technikájára vonatkozó mérési adatok. A kézhigiénés compliance auditálását a vizsgálatot követően 2018 decemberében végeztük. Osztályunk kézhigiénés gyakorlatában alapvetően a WHO által javasolt multimodális implementációs szempontokat követjük [18], a mérések a fenti eloórásoknak megfelelő kézhigiénés környezetben történtek.

A kézfertőtlenítés technikáját elektronikus berendezéssel (Semmelweis Scanner, HandInScan Zrt., Debrecen) mértük. A készülék UV-reagenssel bekevert, gyakorló kézfertőtlenítő szer eloszlását mutatja ki kezenként 2-2 (összesen 4) regisztrált területen, ezáltal valós idejü, vizuális és számszerű visszajelzést ad. A megfelelő kézfertőtlenítést a kézbedörzsölés lefedettsége alapján, tetszólegesen megválasztott határérték szerint különíti el a rendszer. Az eszközzel korábban végzett tanulmány 90\%-os lefedettséget tartott megfelelőnek [19], a jelen vizsgálatban a gyártó javaslata alapján 95\%-os lefedettség visszajelzését választottuk határértékül. A négy közül bármely terület $95 \%$ alatti lefedettsége esetén a kézfertőtlenítést nem megfelelőnek értékelte a rendszer. A résztvevők az első mérésekkor a készülék használatára vonatkozó oktatásban részesültek, egyéb oktatás a vizsgálat során az eredmény visszajelzésétől eltekintve nem történt. Az adatok kiértékelésekor a napi első méréseket vettük figyelembe. A kézfertőtlenítés értékelése során egyrészt a kézfertőtlenítés megfelelősége vagy nem megfelelősége, másrészt lefedettségként a négy regisztrált terület százalékos nagyságának számtani átlaga került feldolgozásra. A kézbedörzsölési technika tendenciájának jellemzésére a vizsgálat három hete során mért lefedettséget hetente is értékeltük, illetve azokat egymással öszszehasonlítottuk.

A kézhigiéné compliance-ét a fenti vizsgálattól függetlenül direkt obszervációs módszerrel mértük. A megfigyelést epidemiológiai szakasszisztens végezte, és az 


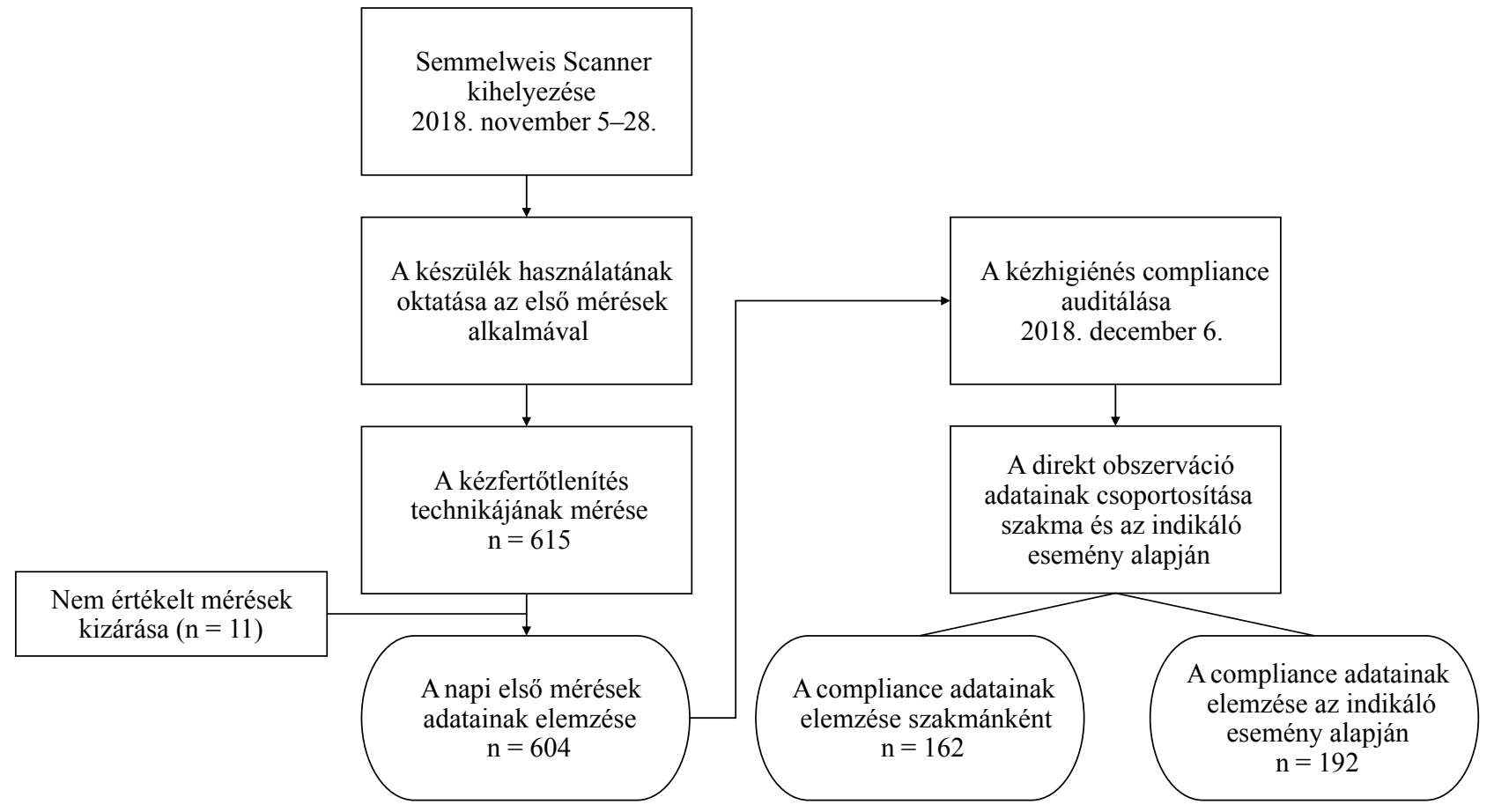

1. ábra $\quad$ A vizsgálat folyamatábrája

eredményeket a WHO által javasolt és nemzetközileg elfogadott adatlapon rögzítette [18], szakmák és a kézhigiéné 5 momentuma alapján csoportosította. A compliance-t a következő képlet alapján számítottuk ki: compliance $(\%)=$ megfelelő indikációjú kézfertőtlenítés / a megfigyelt, kézmosást indikáló események száma.

A statisztikai adatelemzés során a normalitás megítélésére Kolmogorov-Szmirnov-tesztet alkalmaztunk. Adataink nem normáleloszlást követtek, ezért a mediánnal és az interkvartilis tartománnyal jellemeztük óket, illetve az összehasonlító elemzést Kruskal-Wallis-próbával és Dunn-féle post hoc teszttel végeztük. A diszkrét változók közötti kapcsolatot Fisher-féle egzakt teszttel becsültük, ha a kontingenciatáblák valamely értéke 5 vagy annál kevesebb volt, egyébként a $\chi^{2}$-próbát alkalmaztuk. Az egyes próbáknál $\mathrm{p}<0,05$ szignifikanciahatárt vettünk figyelembe. A statisztikai számításokat a Statistica 13.4.0 verziójú (TIBCO Software, Palo Alto, CA, Amerikai Egyesült Államok) programmal végeztük.

A vizsgálat menetét az 1 . ábrán tüntettük fel.

\section{Eredmények}

\section{A kézfertötlenités technikája}

Az elektronikus visszajelző rendszerrel 110 fö összesen 604 értékelhető mérést végzett a vizsgálat során. A legnagyobb elemszámú mérések az orvosok, az ápolók, a segédápolók és a gyógytornászok csoportjában találhatók, így a továbbiakban az ezek közötti különbségeket hasonlítottuk össze, valamint a lefedettség heti alakulását értékeltük.
A megfelelőnek és nem megfelelőnek minősített kézfertőtlenítések arányát hasonlónak találtuk az orvosok és az ápolók $(75,0 \%$ és $86,6 \%, p=0,10)$, az orvosok és a segédápolók $(75,0 \%$ és $85,1 \%, \mathrm{p}=0,19)$, az ápolók és a segédápolók $(86,6 \%$ és $85,1 \%, \mathrm{p}=0,65)$ között, de statisztikailag szignifikánsnak adódott a különbség az orvosok és a gyógytornászok $(75,0 \%$ és $96,0 \%, \mathrm{p}<0,01)$, az ápolók és a gyógytornászok ( $86,6 \%$ és $96,0 \%, \mathrm{p}=0,03)$, valamint a gyógytornászok és a segédápolók $(96,0 \%$ és $85,1 \%, \mathrm{p}=0,03)$ között.

Az összes mérésre vonatkozó lefedettség medián értékei egymástól érdemben nem tértek el az ápolók és a segédápolók között $(99,86 \%$ és 99,87\%, p = 1,00).

\begin{tabular}{l|l} 
1. táblázat & $\begin{array}{l}\text { A visszajelző rendszerrel megfelelónek és nem megfelelőnek } \\
\text { mért kézbedörzsölések összehasonlítása a különböző szakma- } \\
\text { csoportokban }\end{array}$
\end{tabular}

\begin{tabular}{lccc}
\hline Szakmacsoport & \multicolumn{2}{c}{ A mérések száma } & \multirow{2}{*}{$\begin{array}{c}\text { Megfelelt } \\
(\%)\end{array}$} \\
\cline { 2 - 3 } & $\begin{array}{c}\text { Megfelelt } \\
(\mathrm{n})\end{array}$ & $\begin{array}{c}\text { Nem felelt } \\
\text { meg }(\mathrm{n})\end{array}$ & \\
\hline Orvos & 24 & 8 & $75,0 \%$ \\
Ápoló & 318 & 49 & $86,6 \%$ \\
Segédápoló & 120 & 21 & $85,1 \%$ \\
Főnóvér & 5 & 0 & $100,0 \%$ \\
Epidemiológiai felelós & 7 & 1 & $87,5 \%$ \\
Gyógytornász & 49 & 2 & $96,0 \%$ \\
\hline Összesen & 523 & 81 & $86,5 \%$ \\
\hline
\end{tabular}

Magyarázat: a diszkrét változókat abszolút értékben és százalékos formában tüntettük fel. 


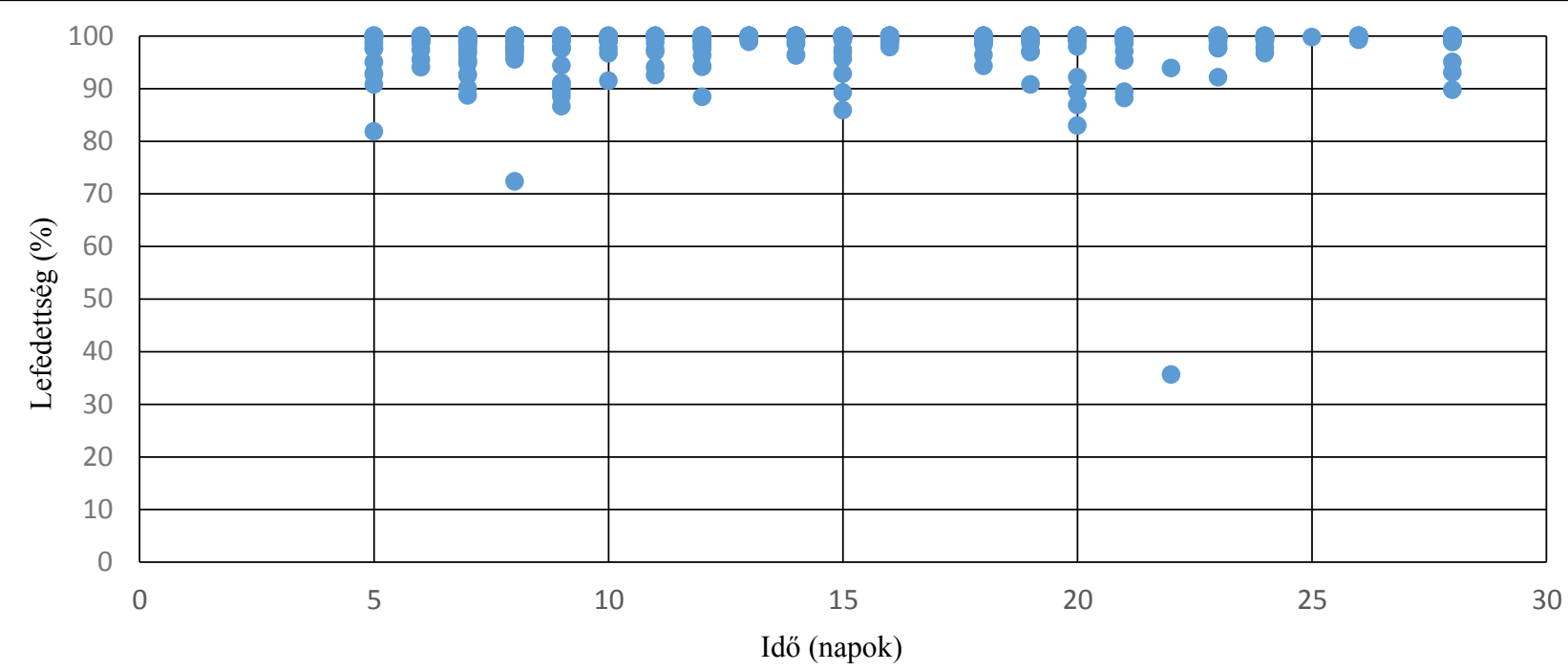

2. ábra

| A lefedettség szórásdiagramja

Ugyanez a változó azonban szignifikáns különbséget mutatott a többi szakmacsoport összehasonlításakor: az orvosok és az ápolók (99,43\% és 99,86\%, p = 0,01), az orvosok és a segédápolók (99,43\% és 99,87\%, p<0,01), az orvosok és a gyógytornászok $(99,43 \%$ és $99,97 \%$, $\mathrm{p}<0,01)$, az ápolók és a gyógytornászok $(99,86 \%$ és $99,97 \%, p<0,01)$, valamint a segédápolók és a gyógytornászok $(99,87 \%$ és $99,97 \%, \mathrm{p}=0,02)$ között.

A lefedettség kezdeti értéke 96\%-nak adódott, és a vizsgálati időszakban jellemzően $95 \%$ felett alakult (2. ábra). Az elsőhöz képest a második hétre a lefedettség szignifikánsan javult $(99,72 \%$ és $99,94 \%, \mathrm{p}<0,01)$, míg a második és harmadik heti lefedettségi értékek kö-

2. táblázat $\mid$ A visszajelző rendszerrel mért lefedettség összehasonlítása a különböző szakmacsoportokban

\begin{tabular}{|c|c|c|c|}
\hline Szakmacsoport & $\begin{array}{c}\text { Lefedettség } \\
\text { a megfelelt } \\
\text { esetekben (\%) }\end{array}$ & $\begin{array}{c}\text { Lefedettség } \\
\text { a nem megfelelt } \\
\text { esetekben }(\%)\end{array}$ & $\begin{array}{l}\text { Lefedettség } \\
\text { az összes } \\
\text { esetben (\%) }\end{array}$ \\
\hline Orvos & $\begin{array}{c}99,72 \% \\
(99,31-99,88 \%)\end{array}$ & $\begin{array}{c}93,55 \% \\
(90,13-96,89 \%)\end{array}$ & $\begin{array}{c}99,43 \% \\
(97,94-99,80 \%)\end{array}$ \\
\hline Ápoló & $\begin{array}{c}99,92 \% \\
(99,56-99,98 \%)\end{array}$ & $\begin{array}{c}95,91 \% \\
(93,53-96,91 \%)\end{array}$ & $\begin{array}{c}99,86 \% \\
(99,17-99,98 \%)\end{array}$ \\
\hline Segédápoló & $\begin{array}{c}99,92 \% \\
(99,60-99,99 \%)\end{array}$ & $\begin{array}{c}94,77 \% \\
(92,53-96,86 \%)\end{array}$ & $\begin{array}{c}99,87 \% \\
(99,29-99,98 \%)\end{array}$ \\
\hline Főnővér & $\begin{array}{c}99,92 \% \\
(99,73-99,96 \%)\end{array}$ & - & $\begin{array}{c}99,92 \% \\
(99,73-99,96 \%)\end{array}$ \\
\hline $\begin{array}{l}\text { Epidemiológiai } \\
\text { felelős }\end{array}$ & $\begin{array}{c}99,94 \% \\
(99,73-99,99 \%)\end{array}$ & $\begin{array}{c}96,35 \% \\
(96,35-96,35 \%)\end{array}$ & $\begin{array}{c}99,83 \% \\
(99,21-99,98 \%)\end{array}$ \\
\hline Gyógytornász & $\begin{array}{c}99,97 \% \\
(99,79-99,99 \%)\end{array}$ & $\begin{array}{c}95,89 \% \\
(93,55-98,23 \%)\end{array}$ & $\begin{array}{c}99,97 \% \\
(99,79-99,99 \%)\end{array}$ \\
\hline Összesen & $\begin{array}{c}99,92 \% \\
(99,60-99,98 \%)\end{array}$ & $\begin{array}{c}95,48 \% \\
(93,35-96,90 \%)\end{array}$ & $\begin{array}{c}99,87 \% \\
(99,24-99,98 \%)\end{array}$ \\
\hline
\end{tabular}

Magyarázat: a folytonos változókat medián (interkvartilis tartomány) formában tüntettük fel. zött nem találtunk különbséget (99,94\% és 99,91\%, $\mathrm{p}=0,97)$.

A különböző szakmacsoportokban a megfelelőnek, illetve nem megfelelőnek mért kézfertőtlenítések abszolút értékét és arányát az 1 . táblázat, ezek lefedettségét a 2. táblázat tartalmazza.

\section{A kézhigiéné compliance-e}

A direkt obszervációs vizsgálat során az egyes szakmacsoportokban összesen 162 megfigyelést rögzítettünk. $\mathrm{Az}$ átlagos compliance-érték 60,49\%-nak adódott. Összehasonlító elemzést a legnagyobb elemszámú csoportokban, az orvosok és az ápolók között végeztünk. A megfigyelt különbség statisztikailag nem szignifikáns $(53,97 \%$ és $62,92 \%, \mathrm{p}=0,26)$.

A különböző szakmacsoportokban megfigyelt, megfelelőnek, illetve nem megfelelőnek minősített indikációval végzett kézfertőtlenítések abszolút értékét és a számított compliance-értéket tartalmazza a 3. táblázat.

3. táblázat | A direkt obszerváció eredményeinek összehasonlítása a külön böző szakmacsoportokban

\begin{tabular}{lccc}
\hline Szakmacsoport & \multicolumn{2}{c}{ A megfigyelések száma } & \multirow{2}{*}{$\begin{array}{c}\text { Compliance } \\
(\%)\end{array}$} \\
\cline { 2 - 3 } & $\begin{array}{c}\text { Megfelelt } \\
(\mathrm{n})\end{array}$ & $\begin{array}{c}\text { Nem felelt meg } \\
(\mathrm{n})\end{array}$ & \\
\hline Orvos & 34 & 29 & $53,97 \%$ \\
Ápoló & 56 & 33 & $62,92 \%$ \\
Segédápoló & 4 & 0 & $100,00 \%$ \\
Gyógytornász & 4 & 2 & $66,66 \%$ \\
\hline Összesen & 98 & 64 & $60,49 \%$ \\
\hline
\end{tabular}

Magyarázat: a diszkrét változókat abszolút értékben és százalékos formában tüntettük fel. 


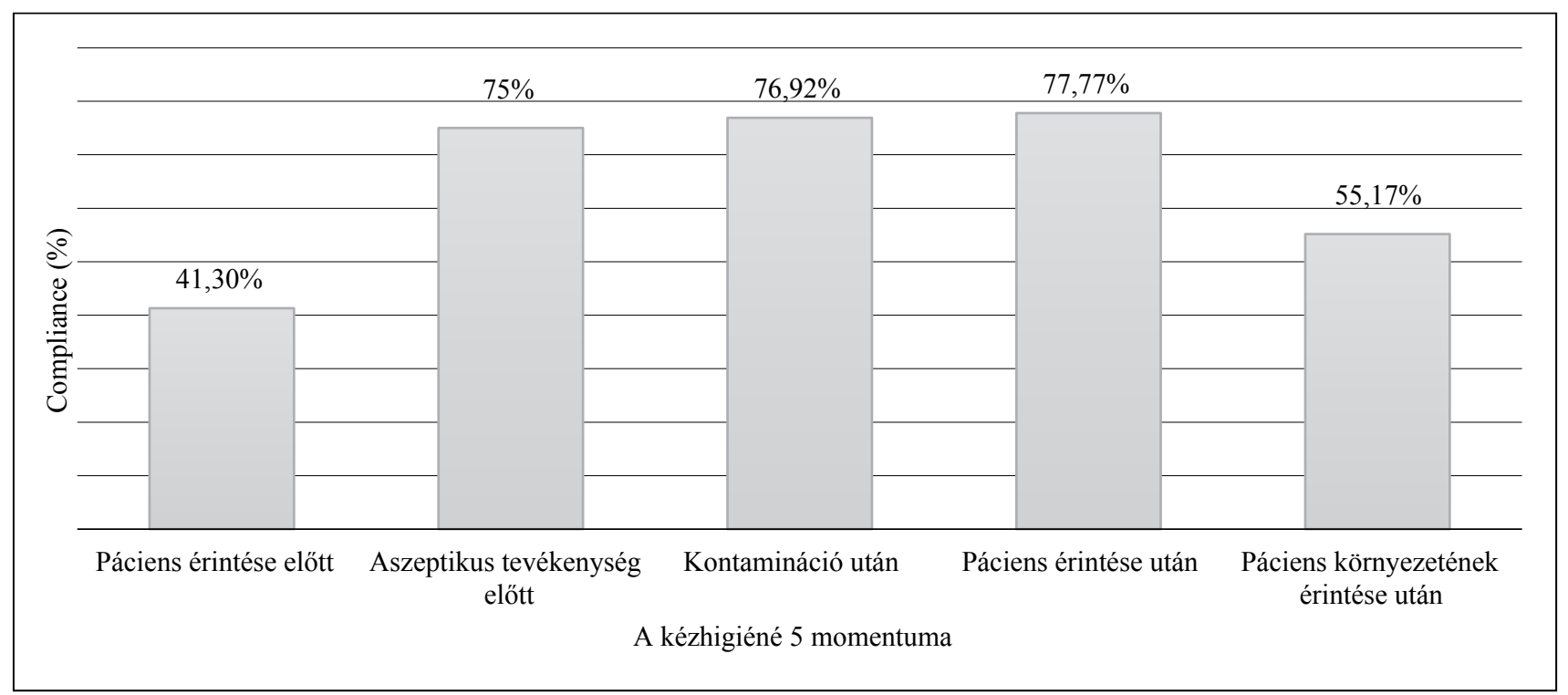

3. ábra

| A direkt obszerváció eredményeinek összehasonlítása a kézhigiéné 5 momentuma alapján

A kézhigiéné 5 momentuma alapján összesen 192 megfigyelést rögzítettünk. A kézfertőtlenítés compliance-e a legkisebb a páciens érintése előtt $(41,30 \%)$ és a páciens környezetének érintése után $(55,17 \%)$ volt (3. ábra).

\section{Megbeszélés}

Az intenzív osztályos infekciókontroll alapvető elemei a helyes kézfertőtlenítési technika és annak megfelelő időzítése a kézhigiéné 5 momentuma alapján. Jelen vizsgálatunkban saját kézhigiénés gyakorlatunk jellemzésével és annak az irodalmi adatokkal való összehasonlításával értékeljük az azonnali visszajelzés lehetséges szerepét ezek elérésében.

A kézfertőtlenítés technikáját a megfelelőnek mért kézbedörzsölések aránya, a lefedettség, valamint ennek időbeli alakulása jellemezte. A megfelelőnek minősített kézbedörzsölések $(86,5 \%)$ magasabb megfelelőséget mutattak az ugyanezzel a berendezéssel 26 magyarországi betegellátó intézményben végzett vizsgálathoz képest (67\%). A fenti mutatók a vizsgálat kezdetétől számítva minden szakmacsoportban magas arányban, majd a vizsgálat teljes ideje alatt megfelelőnek bizonyultak. Megfigyelésünkkel szemben Lehotsky Ákos és mtsai a közel egyenlő számú mérés (631) eredményeit bemutató tanulmányban a kezdetben magas hibaarányt követően folyamatos javulást írtak le [20]. A kézfertőtlenítést jellemző trendek közötti különbséget a már a vizsgálatot megelőzően fennálló magas kézhigiénés standard és a kézmosás helyes technikáját oktató gyakorlatunk hatékonysága magyarázhatja. Osztályunkon alkoholalapú kézfertőtlenítő minden betegágy mellett, egyfázisú kézmosó szappan és egyszer használatos papírtörlő pedig minden kórteremben, tehát maximum 3 betegágyanként elérhető. Az ITO új munkatársai a kézhigiéné jelentőségét hangsúlyozó és a kézfertőtlenítés helyes gyakorlatának elsajátítását segítő, egynapos képzésen vesznek részt. Az ITO bejáratainál, minden csaptelepénél és a kórtermekben a kézhigiéné 5 momentumára vizuálisan emlékeztető poszterek kerültek kihelyezésre.

A gyógytornászok körében a többi szakmacsoporttal szemben észlelt magasabb megfeleltség alapján alaposabb kézmosást feltételezhetünk. Minthogy a lefedettség tekintetében a mutató medián értékei minden csoportban 99\% felett alakultak, az egyes csoportok között adódott statisztikai különbségek klinikai jelentőséget valószínúleg nem jeleznek.

A kézhigiéné átlagos compliance-e $(60,49 \%)$ az irodalomi adatokhoz képest $(30-40 \%)$ magasabb volt [21]. A compliance a legalacsonyabbnak az orvosok körében adódott, ami megfelel a WHO azon megállapításának, mely szerint az orvosi munkakör önmagában az alacsony kézhigiénés compliance független rizikófaktora [18].

A visszajelzés szerepét a kézhigiénés compliance-ben számos tanulmány igazolta $[18,22]$. Tekintettel a vizsgálatot megelőző compliance-adatok hiányára, az azonnali visszajelzés és a kézhigiénés compliance kapcsolatára vonatkozó egyértelmú következtetés nem vonható le.

A vizsgálat limitációját képezi annak az epidemiológiai tanulmányokhoz képest rövid obszervációs ideje. Ugyanezen okból a közlemény az ITO-betegek demográfiáját és a nosocomialis infekciók epidemiológiáját jellemző adatokat nem tartalmazza.

\section{Következtetés}

Elmondható, hogy a kézfertőtlenítés technikája már a vizsgálat kezdetén kiemelkedőnek bizonyult, és az azonnali visszajelző rendszer használata mellett a vizsgálat 
második hetére tendenciózus javulást mutatott. A gyakorló kézfertőtlenítővel elért eredményeink azonban nem párosultak magas kézhigiénés compliance-értékekkel a betegágy mellett. Az orvosi munkakört az irodalmi adatokkal korrelálóan az alacsony kézhigiénés compliance rizikófaktorának találtuk. Az azonnali, vizuális viszszajelzésnek a kézhigiéné megfelelő minőségének elérésében és fenntartásában lehet szerepe, míg a helyes időben, helyes indikációval végzett kézmosás más stratégiát is szükségessé tesz. Megfigyeléseink validálásához, valamint az azonnali visszajelzés és a kézhigiénés compliance közötti kapcsolat jellemzéséhez további vizsgálatok feltétlenül szükségesek.

Anyagi támogatás: A közlemény megírása és a kutatási munka anyagi támogatásban nem részesült.

Szerzői munkamegosztás: I. Zs., Mo. B.: A kutatási téma és metodika kidolgozása. Mo. B., I. Zs.: A kézirat megírása. Mo. B., D. E., Me. B.: Adatgyújtés. Mo. B., Sz. M.: Statisztikai elemzés. H. Cs., G. J.: A kutatási munka felügyelete. A cikk végleges változatát valamennyi szerző elolvasta és jóváhagyta.

Érdekeltségek: A szerzóknek nincsenek érdekeltségeik.

\section{Irodalom}

[1] European Centre for Disease Prevention and Control. Point prevalence survey of healthcare-associated infections and antimicrobial use in European acute care hospitals. ECDC, Stockholm, 2013. Available from: https://ecdc.europa.eu [accessed: May 3, 2019].

[2] World Health Organization. Report on the burden of endemic health care-associated infection worldwide. WHO, Geneva, 2011. Available from: https://apps.who.int [accessed: May 3, 2019].

[3] Vincent JL, Rello J, Marshall J, et al. International study of the prevalence and outcomes of infection in intensive care units. JAMA 2009; 302: 2323-2329.

[4] European Centre for Disease Prevention and Control. Incidence and attributable mortality of healthcare-associated infections in intensive care units in Europe, 2008-2012. ECDC, Stockholm, 2018. Available from: https://ecdc.europa.eu [accessed: May 3, 2019].

[5] Umscheid CA, Mitchell MD, Doshi JA, et al. Estimating the proportion of healthcare-associated infections that are reasonably preventable and the related mortality and costs. Infect Control Hosp Epidemiol. 2011; 32: 101-114.

[6] Leistner R, Kankura L, Bloch A, et al. Attributable costs of ventilator-associated lower respiratory tract infection (LRTI) acquired on intensive care units: a retrospectively matched cohort study. Antimicrob Resist Infect Control 2013; 2: 13.

[7] World Health Organization. Guidelines on core components of infection prevention and control programmes at the national and acute health care facility level. WHO, Geneva, 2016. Available from: https://www.who.int/gpsc/core-components.pdf [accessed May 3, 2019].

[8] Landelle C, Nocquet Boyer VN, Abbas M, et al. Impact of a multifaceted prevention program on ventilator-associated pneumonia including selective oropharyngeal decontamination. Intensive Care Med. 2018; 44: 1777-1786.

[9] van der Kooi T, Sax H, Pittet D, et al. Prevention of hospital infections by intervention and training (PROHIBIT): results of a pan-European cluster-randomized multicentre study to reduce central venous catheter-related bloodstream infections. Intensive Care Med. 2018; 44: 48-60.

[10] Allegranzi B, Pittet D. Role of hand hygiene in healthcare-associated infection prevention. J Hosp Infect. 2009; 73: 305-315.

[11] Pires D, Tartari E, Bellissimo-Rodrigues F, et al. Why language matters: a tour through hand hygiene literature. Antimicrob Resist Infect Control 2017; 6: 65.

[12] Lydon S, Power M, McSharry J, et al. Interventions to improve hand hygiene compliance in the ICU: a systematic review. Crit Care Med. 2017; 45: el165-el172.

[13] Price L, MacDonald J, Gozdzielewska L, et al. Interventions to improve healthcare workers' hand hygiene compliance: a systematic review of systematic reviews. Infect Control Hosp Epidemiol. 2018; 39: 1449-1456.

[14] Wetzker W, Bunte-Schönberger K, Walter J, et al. Compliance with hand hygiene: reference data from the national hand hygiene campaign in Germany. J Hosp Infect. 2016; 92: 328-331.

[15] Chang NC, Reisinger HS, Jesson AR, et al. Feasibility of monitoring compliance to the My 5 Moments and Entry/Exit hand hygiene methods in US hospitals. Am J Infect Control 2016; 44: 938-940.

[16] Szabó R, Böröcz K, Nagy O, et al. Hand hygiene perception among health care workers in Hungarian hospitals: prior to a nationwide microbiological survey. Acta Microbiol Immunol Hung. 2013; 60: 55-61.

[17] Szabó R, Morvai J, Bellissimo-Rodrigues F, et al. Use of hand hygiene agents as a surrogate marker of compliance in Hungarian long-term care facilities: first nationwide survey. Antimicrob Resist Infect Control 2015; 4: 32.

[18] World Health Organization. Guidelines on hand hygiene in health care. WHO, Geneva, 2009. Available from: https://apps. who.int [accessed: May 3, 2019].

[19] Zingg W, Haidegger T, Pittet D. Hand coverage by alcoholbased handrub varies: volume and hand size matter. Am J Infect Control 2016; 44: 1689-1691.

[20] Lehotsky Á, Szilágyi L, Ferenci T, et al. Quantitative impact of direct, personal feedback on hand hygiene technique. J Hosp Infect. 2015 ; 91: 81-84.

[21] Erasmus V, Daha TJ, Brug H, et al. Systematic review of studies on compliance with hand hygiene guidelines in hospital care. Infect Control Hosp Epidemiol. 2010; 31: 283-294.

[22] Walker JL, Sistrunk WW, Higginbotham MA, et al. Hospital hand hygiene compliance improves with increased monitoring and immediate feedback. Am J Infect Control 2014; 42: 10741078.

(Mogyoródi Bence dr., Budapest, Üllöi út 78., 1082 e-mail: mogyorodi.bence@med.semmelweis-univ.hu)

A cikk a Creative Commons Attribution 4.0 International License (https://creativecommons.org/licenses/by/4.0/) feltételei szerint publikált Open Access közlemény, melynek szellemében a cikk bármilyen médiumban szabadon felhasználható, megosztható és újraközölhetö, feltéve, hogy az eredeti szerző és a közlés helye, illetve a CC License linkje és az esetlegesen végrehajtott módositások feltüntetésre kerülnek. (SID_1) 